November 20, 2005

\title{
Trade Unions $v$. Statistical Discrimination: Theory and Application to Post-Apartheid South Africa
}

\author{
by \\ Jean-Paul Azam, \\ University of Toulouse (ARQADE, IDEI) \\ and Institut Universitaire de France, \\ and \\ Sandrine Rospabé, \\ CREM, University of Rennes 1
}

\begin{abstract}
A simple model of statistical discrimination is analyzed, which captures some stylized facts of the South African labor market. It shows that this type of discrimination disappears when the wage rates are determined by efficient bargaining between a representative firm and a union, with endogenous membership. This may explain why the wage gap between Black and White workers in post-apartheid South Africa is smaller among unionized workers than among non unionized ones.
\end{abstract}

Key Words : Labor - Discrimination - Trade Unions - South Africa. JEL : J31 - J51 - J71.

Acknowledgements: This paper was partly written while Sandrine Rospabe was visiting the Australian National University, whose hospitality is gratefully acknowledged. We particularly thank Alison Booth for her useful comments as well as all the participants at the seminar of the Economics Program, RSSS of the ANU, and seminar participants at Cape Town University and at Louvain-la-Neuve and two anonymous referees. It is part of the Polarization and Conflict Project CIT-2-CT-2004-506084 funded by the European Commission-DG Research Sixth Framework Programme. This article reflects only the author's views and the Community is not liable for any use that may be made of the information contained therein.

\section{Corresponding author :}

Jean-Paul Azam,

ARQADE, Université des Sciences Sociales

21, Allée de Brienne, 31000 TOULOUSE

Tel : 33 (0) 5611285 35, Fax : 33 (0) 561128538

Email : azam@univ-tlse1.fr 


\section{Introduction.}

Wage discrimination between White workers and Black workers in South Africa was repugnant, for the outside observer, but seemed easy to explain because of the apartheid system. While the latter has been dismantled in the late 1980s, discrimination does not seem to have disappeared in this country after the fall of apartheid, although it has probably been reduced in many sectors. Hence, some other incentive for discrimination must be at work in the South African labor market, to explain the lasting discrimination. Moreover, various pieces of empirical work, discussed below, suggest that the remaining discrimination is much less pronounced in the unionized sectors than in the non unionized sectors.

The present paper provides a simple model that captures these two stylized facts of the South African labor market: (i) there is probably a deep cause of discrimination in the labor market, which has survived the dismantling of apartheid, but (ii) its effects seem to be offset to a large extent by unionization. However, the theoretical model presented is potentially suitable for of a wider application than the single case of South Africa, as apartheid as such plays no part in it. It is based on statistical discrimination theory, which assumes some imperfect information of employers about the productivity of each individual worker, while Blacks and Whites are supposed to have a different probability distribution over their productivity levels, known to the employers. Hence this model could be applied to other types of discrimination, e.g. by gender, provided the dividing line between the groups is drawn according to some significant differences in the probability distributions over the productivity levels of their members. This simple model can be used equally under perfect competition on the labor market, or under the assumption of bargaining between a representative firm and a trade union. Comparing the competitive equilibrium to the outcome resulting from the action of the trade union brings out the impact of trade unions on discrimination, showing that the latter changes its nature. Under reasonable assumptions, the trade union is thus shown to reduce discrimination ${ }^{1}$.

\footnotetext{
${ }^{1}$ Myles and Naylor (1995) discuss the impact of unionization on discrimination, when the employer has an unexplained taste for the latter, as in Becker (1957). Discrimination is also reduced in that model by the union.
} 
The next section reviews the history of discrimination and of trade unions in South Africa, and discusses some statistical evidence describing the differences between Black and White workers, regarding their average wage levels, their involvement in the trade union movement, and their education levels. Section 3 presents the model, discussing the effect of statistical discrimination in the competitive equilibrium. The impact of unionization on wage discrimination is analyzed next, in section 4 . Section 5 is devoted to a deeper econometric analysis of racial discrimination in the South African labor market in 1999.

\section{The Influence of South African Trade Unions on Discrimination.}

This section discusses the evolution of the legal setting concerning the South African labor market, and presents some descriptive statistics that bring out the extent of the remaining racial discrimination, and its plausible causes.

\section{From Legal to Statistical Discrimination.}

A special feature of discrimination in the South African labor market has for a long time been its legal backing by the government. A set of laws and tacit agreements has influenced the functioning of this market by establishing a racial wage and job organization ${ }^{2}$. Some important discriminatory steps were undertaken either before or during the apartheid regime. In 1924, access to official collective bargaining was refused to Black workers. Then, at the end of the 1940's, a policy of "influx control" was adopted, which limited the geographical mobility of Black workers and thus the competition faced by Whites from workers accepting lower wages and poorer working conditions. Another measure was the introduction, in 1956, of a system of "job reservation", whereby some occupations were legally reserved to a particular racial group. For several decades, this legislation created a favorable environment for employers and White workers to discriminate against Blacks, by limiting the latter's access to the same wage rates and jobs as Whites. However, several factors gradually revealed to the government the economic and social misdeeds imposed by the apartheid policy. The rise in union demands certainly favored this awareness. The labor market began to suffer badly from a shortage of skilled labor, as a consequence of both the

\footnotetext{
${ }^{2}$ For further details see Griffiths and Jones (1980).
} 
exclusion of Blacks from a performing education system and of the reservation of training opportunities to White workers. Moreover, the impediments to geographical and professional mobility have hindered the efficient allocation of labor between different activities and job categories. It also became difficult for the government to justify the continuation of its policy in front of social unrest, especially the Soweto riots in 1976 and the mushrooming industrial strikes. The international sanctions against the regime, by limiting foreign investment, also contributed to the policy change that M. P. W. Botha implemented at the end of the 70's. Following the recommendations of the Wiehahn and Riekert Commissions, the government liberalized gradually its racial policy, allowing in 1979 Black unions to participate in collective bargaining, and dismantling in the 1980's the systems of "influx control " and "job reservation". Most of the discriminatory laws disappeared at the end of the $80^{\prime}$ s, in favor of more freedom in labor relations. However, this does not entail that discrimination, deeply ingrained in labor relations, has been totally eradicated by the progressive legislation.

Hence, several studies (Allanson et al. (2000), Hinks and Watson (2001), Knight and McGrath (1987), Moll (1992, 1995), Rospabé (2002)) aimed at estimating the degree of wage discrimination between South African workers of different races. Knight and McGrath as well as Moll conclude that wage discrimination has been decreasing over the 1970s and 1980s. However, Rospabé (2002) shows that wage discrimination between Blacks and Whites slightly increased in the second half of the 1990s. Nevertheless, all these studies concur in finding that there is still a large percentage of the wage gap remaining to be explained. During the 1990's, the remaining racial wage discrimination cannot reflect anymore, or only retrospectively and to a much lower extent, the impact of labor legislation. It must be explained by other factors.

The legacy of apartheid can not be neglected. It seems too that discrimination "prior to the labor market", in the acquisition of human capital, influences wage inequality to a large extent. Table 1 shows that White workers have on average 1.5 times as many years of education as Black ones, and a lower dispersion in their educational record. Regarding years of education as a proxy for the workers' skills when they arrive on the labor market, these 
data suggest that, at the time of hiring, the average White workers' productivity is higher than Black workers' productivity, and that the variance of productivity is larger for Blacks than for Whites ${ }^{3}$.

Table 1 : Years of Education for Male Workers of Each Population Group.

\begin{tabular}{ccc}
\hline Years of education & Black Workers & White Workers \\
\hline Mean & 7.5 & 12.2 \\
Standard deviation & 4.2 & 1.7 \\
\hline
\end{tabular}

Source: October Household Survey 1999 (Statistics South Africa).

This suggests that the origin of wage discrimination in the South African case requires another kind of discrimination theory. We focus here on statistical discrimination theory, which is able to explain unequal wages paid to equally productive workers when the employer faces a situation of imperfect information on the workers' characteristics, and is then confronted with a productivity risk ${ }^{4}$.

Such models differ from Becker's work (1957), which assumes an exogenous taste for discrimination. Two major theoretical considerations are leaning against this standard model of discriminatory tastes. First, this theory cannot explain the persistence of a long-run wage gap, as discriminating firms would be driven out of business by competition. Second, it does not seem to fit with even a casual observation of the South African labor market. The main cause of racial wage discrimination was never linked to the employers' physical or social aversion against Black workers, but rather to a White workers' fear to lose their status by sharing their jobs with the latter (Knight and McGrath, 1977). These White workers used to put some pressure on employers, pushing the Black workers' wages above their marginal productivity. However, this is no more relevant after the end of apartheid. In the model presented below, it is the employer's uncertainty about workers' quality which perpetuates wage discrimination, at least in the non unionized sector.

The two best known models of statistical discrimination are those of Arrow (1973) and Phelps (1972). A standard version of the latter is presented by Aigner and Cain (1977).

\footnotetext{
${ }^{3}$ These results are important for the relevance of our model's assumptions to the South African case. ${ }^{4}$ Frijters (1999) analyzes hiring practices in a South African clothing firm. He shows that the observed screening of African workers for hiring could be explained by statistical discrimination.
} 
The two models differ by the assumptions made on the productivity signal sent by the worker. In Arrow's model (Arrow, 1973), employers make a hiring test that unveils the worker's true productivity. The wage gap comes from the employers' subjective opinion about the probability that a worker randomly selected in the two racial groups be skilled. In the models developed by Phelps (1972) and Aigner and Cain (1977), the test (or signal) is an imperfect indicator of the individual productivity. Although the population distribution is known, the actual productivity of any worker is unobservable. Firms only observe an unbiased noisy signal of productivity. Wage discrimination originates from the Black worker's signal being less informative than the White worker's one. However, these models do not explain different average wages for distinct racial groups. Discrimination is individual and intra-group in these models, and does not explain the residuals observed in econometric studies. Various models generating such a between-group wage difference have been produced. In Lundberg and Startz (1983), wage discrimination depends on the signal noise and on the fact that workers can make either unobservable or observable productivityenhancing investment in human capital prior to entering the labor market. Oettinger (1996) develops a dynamic statistical discrimination model in which productivity is learned after one period on a job, and predicts that a Black-White wage gap emerges only as labor market experience accumulates. In order to explain the long-run wage discrimination we present a simple theoretical model of statistical discrimination in section 3, which captures in the employers' and unions' objective functions some specific features of the South African case.

\section{The Impact of the Trade Unions.}

Various authors have recently come up with some estimates of the impact of South African trade unions on wages, using micro-economic data (Butcher and Rouse (2001), Fallon and Lucas (1997), Hofmeyr and Lucas (2001), Moll (1993, 1995), Mwabu and Schultz (1998) and Rospabé (2001)). They reveal a significant wage differential between unionized and non unionized workers, particularly significant for Blacks, but quite small for White workers. All their findings suggest that unions influence significantly the bargaining of Black wages, to a larger extent than those concerning White wages. This comes out also from the following descriptive statistics. 
Table 2 : Unionization According to Population Groups (male workers)

\begin{tabular}{lccc}
\hline & $\begin{array}{c}\text { Black and White } \\
\text { workers }\end{array}$ & Black workers & White workers \\
\cline { 2 - 4 } & 1638779 & 1362036 & 276742 \\
Number unionized & 3880267 & 3105077 & 775190 \\
Total number of workers* & $42.2 \%$ & $43.9 \%$ & $35.7 \%$ \\
Unionization rate &
\end{tabular}

Source: OHS 1999.

Note: * employees reporting their union status. Unionization rates are thus likely to be overestimated.

Table 3: Average Monthly Gross Earnings (in Rand) by Population Groups and Union Status (male workers).

\begin{tabular}{lccc}
\hline Union Status $\backslash$ Gross Wages & Black Workers & White Workers & $\begin{array}{c}\text { Ratio of Earnings of } \\
\text { Whites to Blacks }\end{array}$ \\
\hline Union members & 3308.5 & 8286.5 & $2.5: 1$ \\
Non members & 1933.2 & 7935.2 & $4.1: 1$ \\
Ratio of Earnings of union & 1.71 & $1.04^{*}$ & \\
members to non members & & & \\
\hline
\end{tabular}

Source : OHS 1999.

Note: * not statistically significantly different from 1 .

Table 2 presents the numbers of unionized workers. With unionization rates as high as $35 \%$, or above for both Black and White workers, South Africa is among the most unionized developing countries. Furthermore, these figures show that Black workers have a higher unionization rate than Whites, since more than $43 \%$ of Black employees are unionized, whereas only slightly more than a third of the Whites are union members. Table 3 shows that there are large differences in earnings between workers of different race and union status. On average, Black union members earn more than non members (about 70\% more), whereas there is no significant difference in wages between White unionized and non unionized workers. Thus, the racial wage gap is larger in the non-union sector than in the union sector. 


\section{Figure 1. Black Male Workers' Earnings Distribution (OHS 99)}

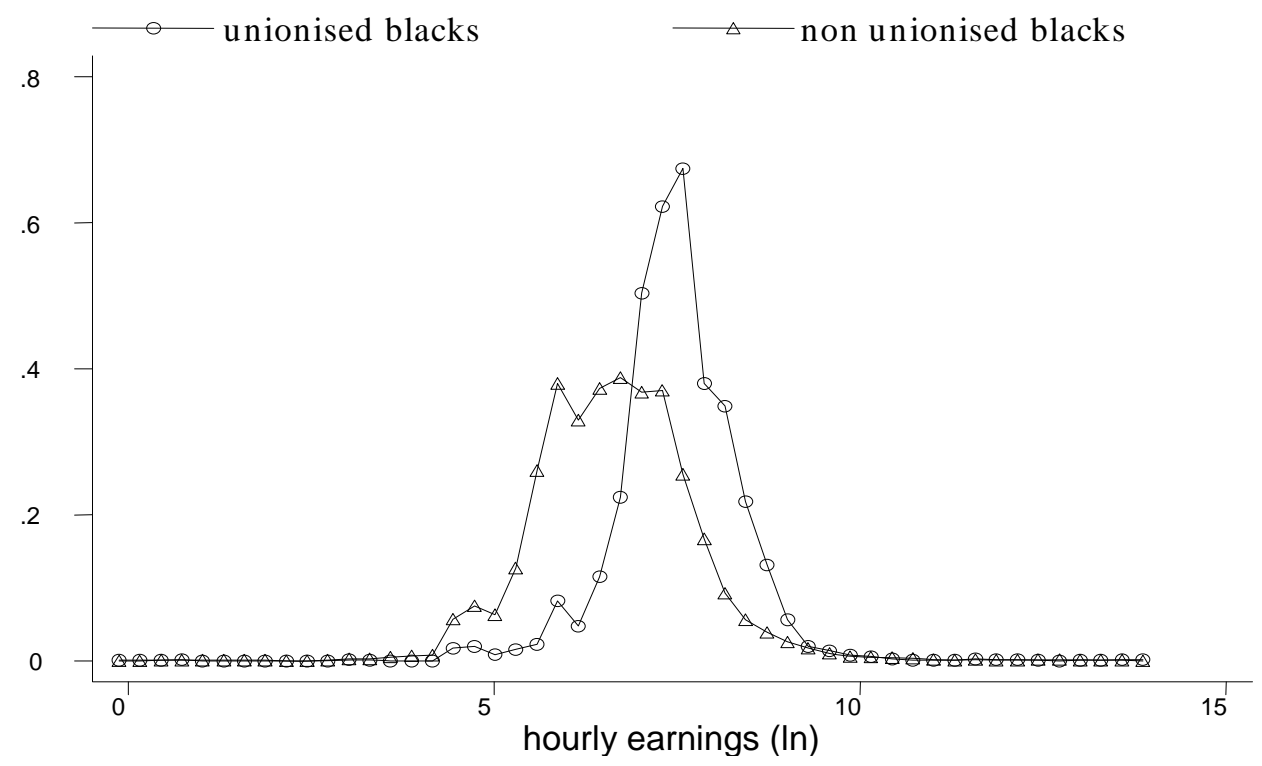

Figure2. White Male Workers' Earnings Distribution (OHS 99)

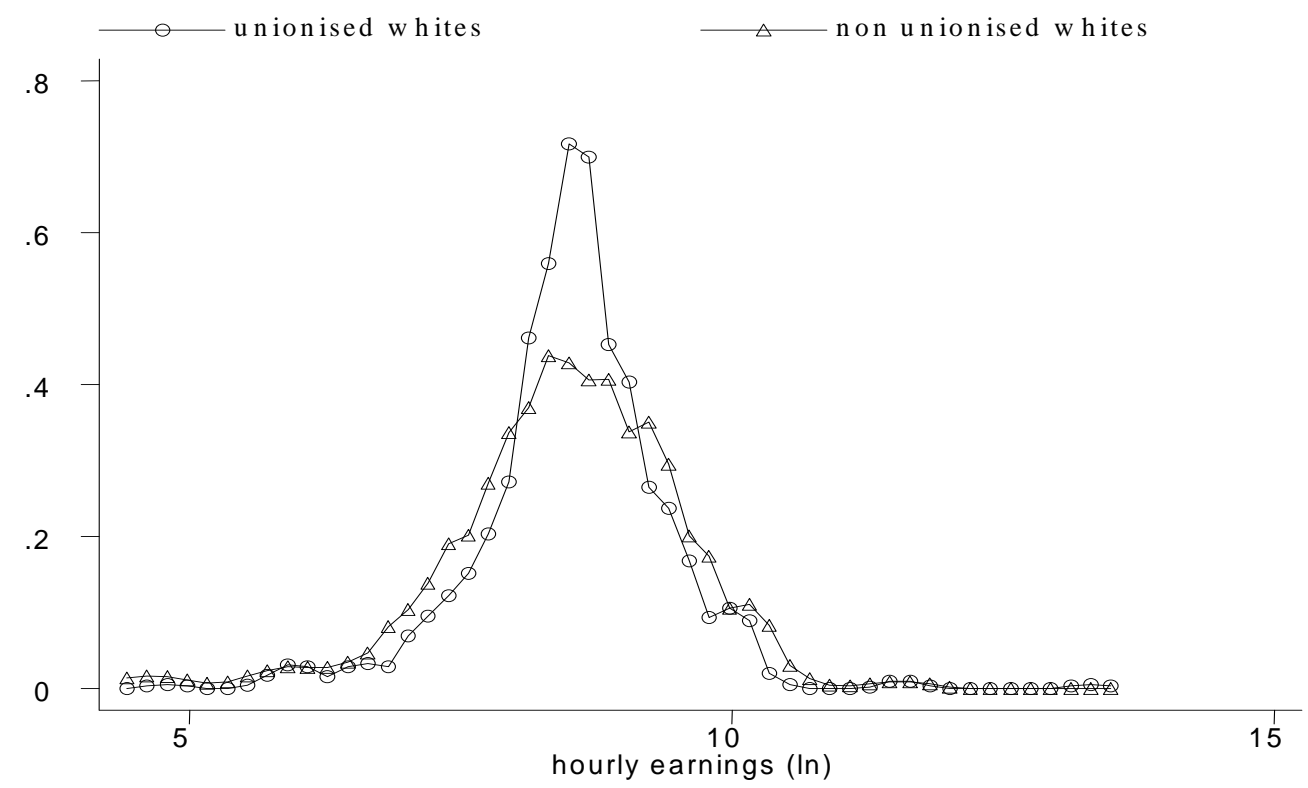

Figure 1 shows that unionization entails two main differences in the Black workers' earnings distribution. First, the latter is shifted to the right, towards higher wages for unionized workers. Second, the wider dispersion of the distribution among non unionized workers shows a stronger wage inequality in the non unionized sector. For Whites, the shapes of the earnings distributions are more similar for the two types of workers, with a 
slight tendency towards wider inequality among non unionized workers, as shown by figure $2^{5}$. The econometric estimations presented in section 5 go beyond this descriptive analysis of the impact of unionization on racial wage discrimination remaining in South Africa in 1999, by controlling for many other determinants of the wage rates.

This visible importance of trade unions cannot be understood without a prior description of the gradual inclusion of Black workers in the trade union movement. Since 1924, the official system of collective bargaining has mainly relied on the Industrial Councils ${ }^{6}$, comprising one or several trade unions and employers, registered under the law. Until 1979, every union representing "pass bearing" employees was excluded from registration and hence from the statutory system. During several decades, White workers have supported as voters the discriminatory labor legislation. Because only White unions were allowed to bargain, they were in a strong position and thus reinforced discrimination against Black workers. However, in 1930, an amendment to the Industrial Conciliation Act stipulated that each Industrial Council agreement could be extended, after a Labor Minister decision, to all workers in the industry, belonging or not to a trade union involved in the bargaining. In 1925 was voted the Wage Act, which allowed for minimum wage rates (called "wage determination") in industries or occupations not covered by statutory bargaining structures. Although Black trade unions' activity was discouraged, several unions were created under different forms: parallel unions (working with liberal registered unions), independent unions, non racial unions and exclusively Black unions, linked to the Africanist or the Black Consciousness movements. These unions tried to make up for the lack of representation by getting recognition at the plant level. The first recognition agreement of a Black union was signed in 1974. However, they did not really contribute to shifting the discriminatory trend until the 1980's.

In 1979, following the Wiehahn Commission's recommendations, participation in statutory collective bargaining was opened to all trade unions. This radical change was

\footnotetext{
${ }^{5}$ One of the methods often used by unions for reducing wage inequality is to impose a system of "rate for the job" for determining wages, which is perceived as a constraint on employers' arbitrariness. However, in the days of apartheid, this principle was used by White workers' unions for excluding Blacks from some jobs (Crankshaw, 1997).

${ }^{6}$ Renamed Bargaining Councils in the new Labor Relations Act of 1995.
} 
aimed at controlling better Black unions and preventing proliferation of plant level recognition agreements. Nevertheless, it did not stop the development of a two tier bargaining system. The 1980s witnessed an increase in Black membership and in the bargaining power of the emerging Black and multiracial trade unions, while White unions lost a lot of their influence. Progressive unions began to play a role in the reduction of the racial wage gap. There is quite a lot of diversity in the South African bargaining system across industries and across firms. Wage bargaining takes place at two levels in South Africa. At the centralized level, wages are set in Bargaining Councils agreements, which cover specific industry, occupation and area (either the whole country, or a province or city $)^{7}$. As seen above, these agreements can be extended to non-parties (though exemptions are not uncommon, as shown by Standing et al., 1996). According to Butcher and Rouse (2001), in 1995, approximately $16 \%$ of the employed workers were covered by this kind of agreement. Among the covered workers, respectively 42\% (33\%) of the Blacks (Whites) were unionized. At the plant-level, bargaining occurs both in the firms covered and not covered by Bargaining Council agreements. In the first case, the bargaining raises the wages paid to some workers above those set in the agreements. Together with various exemptions, this additional bargaining explains how a union wage premium can occur within firms covered by Bargaining Councils agreements. When no Bargaining Council exists (for $84 \%$ of the employees), plant-level bargained wages mainly affect unionized workers as unionization is highly concentrated in some firms, the others not being covered by any wage bargaining. About 37\% (21\%) of the Black (White) not covered workers are union members. Therefore, the pattern of collective bargaining in South Africa is drawing a distinction between a unionized sector and a non-unionized sector, as a first approximation, although some unionized workers are found in the latter.

The model below uses this stylized fact ${ }^{8}$, and seeks to explain the origin of the racial wage gap in a competitive environment and its change under union bargaining.

\footnotetext{
${ }^{7}$ Note that the mining sector has no Bargaining Council but a so-called Agreed Bargaining Forum.

${ }^{8}$ Furthermore, a look at the OHS 1999 data shows that union employment is mainly concentrated in three industrial sectors, namely mining, manufacturing and service.
} 


\section{The Model: Statistical Discrimination in the Competitive Case.}

We analyze here the wage discrimination that may occur within a representative firm. Workers are divided into two racial groups, each being comprised of $N_{j}$ workers $(j=W$ for Whites and $B$ for Blacks). The distribution of productivity is known for each group but the actual productivity of any given worker is unobservable.

\section{Random Productivity}

Output is a random variable and the production function is specified as follows:

$$
Y=\sum_{i=1}^{N_{W}} \theta_{i W}+\sum_{i=1}^{N_{B}} \theta_{i B}
$$

where the productivity of each worker $i$ of race $j$ is a noisy function of the average productivity of that group. It is determined as follows:

$$
\theta_{i j}=\theta_{j}(N)+\varepsilon_{i j}, \quad \text { where } N=N_{W}+N_{B}
$$

We assume that each worker's productivity is decreasing with the total number of workers employed in the firm, be they Black or White, hence $\theta_{j}{ }^{\prime}(N)<0$. This captures in a simple fashion the kind of congestion effect which is usually assumed with standard production functions, as a rationale for decreasing marginal returns to labor, given the capital stock. We further assume that $\theta_{j}{ }^{\prime \prime}(N)<0$.

We assume that the distribution of $\varepsilon_{i j}$ is such that:

$$
E\left(\varepsilon_{i j}\right)=0 \text { and } \operatorname{Var}\left(\varepsilon_{i j}\right)=\sigma_{j}^{2}
$$

Thus, the expectation and variance of productivity, conditional on $N$, are given by:

$$
E\left(\theta_{i j}\right)=\theta_{j}(N) \text { and } \operatorname{Var}\left(\theta_{i j}\right)=\sigma_{j}^{2}
$$

In order to capture the wider dispersion of education levels between Blacks and Whites, seen at table 1, we can assume that the variance of the productivity of Blacks is higher than the variance of the productivity of Whites $\left(\sigma_{B}^{2}>\sigma_{W}^{2}\right)$. This assumption is not strictly needed for the results presented below, but it adds realism to the model. Indeed, the 
environment of human capital accumulation appears to have been more heterogeneous for Black than for White workers9.

We also assume that Black workers have a lower average productivity than White ones. Thus, we take discrimination "prior to the market" into account. The lower average human capital stock accumulated by Black people may originate from a poorer quality and quantity of schooling than the one received by Whites ${ }^{10}$. Then, $\theta_{B}(N)<\theta_{W}(N)$.

Given these assumptions, expected output is given by:

$$
E(Y)=N_{W} \theta_{W}(N)+N_{B} \theta_{B}(N)
$$

This production function displays positive and diminishing marginal returns to each type of labor, under the following assumption. Denote $E_{j}^{\prime}(N)$ the expected marginal productivity for each group of workers, given by :

$$
\frac{\partial E(Y)}{\partial N_{j}}=\theta_{j}(N)+\sum_{j=W, B} \theta^{\prime}{ }_{j}(N) N_{j}
$$

which is positive by assumption. In this model, the expected marginal productivity of a worker is made of two parts: the expectation of her own productivity, as defined in (2), minus the fall in the sum of the expected productivity of all the other workers in the firm, which may be called the congestion effect. The marginal productivity of a worker is thus positive as long as the former dominates the latter.

Given the assumptions made about $\theta_{j}{ }^{\prime}(N)$ and $\theta_{j}{ }^{\prime \prime}(N)$, this expected marginal productivity is decreasing with $N_{j}$ because:

$$
\frac{\partial^{2} E(Y)}{\partial N_{j}{ }^{2}}=2 \theta_{j}^{\prime}(N)+\sum_{j=W, B} \theta_{j}{ }^{\prime \prime}(N) N_{j}<0
$$

\footnotetext{
${ }^{9}$ This assumption is in agreement with the figures presented in the previous section. Furthermore, the earnings equations presented below at tables $2 \mathrm{~A}, 3 \mathrm{~A}$, and $4 \mathrm{~A}$, in the appendix, confirm that education is a major determinant of productivity, as reflected in the earnings in the competitive sector, as well as in the unionized sector. Thomas (1996) also shows that dispersion of education among Blacks has increased over the last half-century.

${ }^{10}$ Empirical results found by Moll $(1995,1998)$, Case and Deaton (1999) and Thomas (1996) seem to support this idea.
} 


\section{The Firm's Risk Aversion and Competitive Wages}

The firm is assumed to be unable to insure all the productivity risk that it faces, and is thus affected by risk aversion. This is captured here by assuming that it maximizes a differentiable concave utility function $V^{F}$, of the standard mean-variance type ${ }^{11}$. This is a simple way of capturing risk-aversion that takes into account both the productivity and the risk of employing the workers belonging to each group, with different variances of productivity.

For the sake of simplicity, we specify the objective function of the firm as:

$$
\operatorname{Max}_{\left\{N_{W}, N_{B}\right\}} V^{F}=E(\Pi)-\alpha\left(N_{w} \sigma_{W}^{2}+N_{B} \sigma_{B}^{2}\right)
$$

where:

$$
E(\Pi)=E(Y)-\bar{w}_{W} N_{W}-\bar{w}_{B} N_{B}
$$

In this expression, $\bar{w}_{W}$ and $\bar{w}_{B}$ are the competitive wage rates for each type of workers. The linear specification of the impact of the productivity variance of each type of workers in (5) allows to write the marginal cost of employing each worker as: $\bar{w}_{j}+\alpha \sigma_{j}^{2}, j \in\{W, B\}$. Thus, $\alpha$ represents the correction factor that the firm is using for pricing the cost of productivity risk. Given this risk-adjusted profit function of the representative firm, we can prove the following proposition.

Proposition 112: In the competitive case, statistical discrimination results in the following wage differential between White and Black workers:

$$
\bar{w}_{W}-\bar{w}_{B}=\left(\theta_{W}(N)-\theta_{B}(N)\right)-\alpha\left(\sigma_{W}^{2}-\sigma_{B}^{2}\right) .
$$

As we have assumed $\theta_{B}(N)<\theta_{W}(N)$ and $\sigma_{B}^{2}>\sigma_{W}^{2}$, we can conclude that the wage paid to White workers is higher than the Black workers' one. Equation (7) shows the two potential sources of statistical discrimination, namely the difference in the average

\footnotetext{
${ }^{11}$ Ruling out full insurance against productivity risk as we do here may be justified by the standard moral hazard argument.

${ }^{12}$ All the proofs are rejected in the appendix.
} 
productivity of the workers in each group, and the difference in the variance of their productivity. Notice that this model can encompass cases where one group of workers is not dominated on both accounts. We might have a positive wage differential even if the relative ranking of the two groups according to the two criteria was of opposite sign: for example, the high-mean group might have a higher variance too, and still earn more, if the former effect dominates the latter. Moreover, if the risk aversion of the employers is high enough, with a large $\alpha$, then the difference in variance is all that matters.

Equation (7) sheds an interesting light on the political economy of apartheid. The pass system and the job reservation policies were aiming mainly at affecting the Black workers' competitive wage. Then, the White nationalist unions were all powerful, and had been able to impose these measures (see Wintrobe, 1998). The relationship between the level of employment and the competitive wage gap can be derived by using (7). Then, an increase in the alternative-wage gap is consistent with a restrictive hiring policy, as was observed in those days, if $\theta_{W}{ }^{\prime}(N)-\theta_{B}{ }^{\prime}(N)<0$, i.e. if the congestion effect, at the margin, is stronger for White workers than for Black workers.

Thus, this simple model of statistical discrimination, accounting for the presence of discrimination prior to the market, can capture the kind of wage discrimination and the between-group wage differential that is observed empirically. The next section extends this framework to analyze the impact of trade unions.

\section{The Role of Trade Unions: Efficient Bargaining $v$. Statistical Discrimination.}

Not all workers of each race are union members ${ }^{13}$. Thus we want a simple model where membership is endogenous. In this respect, the assumption made below is close to that presented in Booth (1984). Since the end of Apartheid in South Africa, the trade unions

13 The Labour Relation Act (1995) stipulates that a representative trade union and an employer organization may conclude a closed shop agreement, requiring all employees covered by the agreement to be members of the trade union, following some specific conditions. Although there are no official figures on the extent of the closed-shop, it seems to concern only a minority of workers. However, the legislation also deals with the free rider issue by permitting agency shop agreements that require the employer to deduct an agreed agency fee from the wages of its employees who are identified in the agreement and who are not members of the trade union. 
have played a definite political part, in pushing for clearing the labor market of the residual discrimination that can still be observed there, as suggested in the previous section. Then an important question to ask is why both types of workers get involved in the unions.

\section{The Trade Union Objective Function}

The literature on the open shop trade union has emphasized the non-pecuniary private benefits that union membership provides to their members, beside the expected monetary rewards (Booth, 1985, Booth and Chatterji, 1993, Naylor, 1989, Naylor and Cripps, 1993). They emphasize reputation effects, for compliance with social norms. In the South African case, it is probably even more important, as far as White workers are concerned, to emphasize the enhanced self-esteem due to a sense of commitment to a progressive cause. Moreover, they might also join the union with a hope of getting some job protection, in front of the extension of the affirmative action policy officially adopted recently. In order to take this type of effects on board, we assume that a worker of group $j$ gets a non-pecuniary reward worth $r_{j}, j \in\{W, B\}$, beside the expected monetary one, when joining the union ${ }^{14}$. In addition, a group $j$ worker incurs a membership cost worth $\gamma_{j}, j \in\{W, B\}$. This may capture both the monetary contributions that may be required from union members and the value of the time that they have to invest in union activity.

The trade union is assumed as usual in this literature to aggregate somehow the preferences of its members. In this respect, we follow the standard approach of specifying a utilitarian objective function for the union. For $j \in\{W, B\}$, denote $L_{j}$ the number of union workers, $N_{j}$ employment in the unionized sector, $\bar{w}_{j}$ the alternative sector wage or the unemployment benefit and, $v\left(w_{j}\right)$ the increasing and concave utility function of the representative member. However, we extend this formulation by allowing for the possibility that the union may also discriminate between the two groups of workers. Taking into account the non-pecuniary benefits as well as the cost of membership defined above, union preferences are given by:

\footnotetext{
${ }^{14}$ For the sake of simplicity, this non-pecuniary reward is assumed exogenous. An interesting extension would be to assume that it depends on the level of union membership, as in Booth (1985) and Naylor (1989).
} 


$$
V^{u}=\sum_{j \in\{W, B\}} \beta_{j}\left(N_{j} v\left(w_{j}\right)+\left(L_{j}-N_{j}\right) v\left(\bar{w}_{j}\right)+\left(r_{j}-\gamma_{j}\right) L_{j}\right)
$$

If $\beta_{W}>0$ and $\beta_{\mathrm{B}}=0$, the union only values the White workers' interests and then discriminates against Black workers ${ }^{15}$. This situation can be representative of the behavior of a few South African nationalist unions during the apartheid regime, e.g. the South African Confederation of Labor. However, since the Labor Relation Act of 1995, such a race-based behavior is prohibited. If $\beta_{W}=0$ and $\beta_{\mathrm{B}}>0$, the union only takes into account the rent accruing to the Black workers. Some South African unions, Africanist or Black Consciousness oriented, seem to support this kind of policy. Finally, when $\beta_{W}>0$ and $\beta_{\mathrm{B}}>0$, the union weighs the rents accruing to each of the two groups of workers. It is probably the case of the multi-racial unions which nowadays dominate the union scene.

\section{The Structure of the Game}

Assume that the game takes place in two stages. At stage one, all the workers correctly forecast the wage and employment level that the union is going to give to its members from each group, because the parameters of the model are common knowledge. Workers freely join the union as long as the expected utility derived from doing so, taking due account of the non-pecuniary benefits and costs of membership, is larger than the expected utility of working in the non-unionized, or competitive, sector. Union membership is thus modeled as resulting from free entry of the workers into the unionized sector of the economy. We assume that the economy is clearly divided into two sectors, with the labor force employed in the unionized sector being small enough to leave the wage rate in the competitive sector unaffected. The latter is determined as described in the previous section, for a fixed supply of labor. Then, bargaining takes place given the membership level.

There are mainly two approaches to modeling the bargaining behavior of trade unions: it is either assumed that bargaining concerns only the wage rate, the firm choosing unilaterally the employment level - it is the 'right-to-manage' model (Nickell, 1982, Booth and Chatterji, 1995) - or that the union and the firm simultaneously determine wages and

\footnotetext{
${ }^{15}$ One could specify $\beta_{B}=1-\beta_{W}$, as is often done in this type of objective function. However, there is no point in so restricting the sum $\beta_{W}+\beta_{B}$ as what matters is only the ratio $\beta_{W} / \beta_{B}$ (see e.g. (12) below).
} 
employment - it is the efficient bargaining model (McDonald and Solow, 1981). The choice of the efficient bargaining model is often justified by its efficiency properties. Indeed, the wage and employment outcome of the right-to-manage model lies on the labor demand curve, and hence is Pareto inefficient. This can be viewed as resulting from the inability of the firm to commit credibly to the agreed upon employment level. When bargaining concerns both wages and employment, the outcome is located on a contract curve, defined as all possible points of tangency between the iso-profit and union indifference curves, and is then Pareto efficient. In other respects, although there is some evidence to suggest that unions and firms emphasize bargaining over wages only, it seems that the available empirical research is unable to discriminate between the two models (Booth, 1995).

Thus, in the second stage of the game, the union bargains over wage and employment levels with the representative firm. As seen previously, this is meant to capture the working of the bargaining councils, which exist in some industries in South Africa as well as the plant-level bargaining. The equilibrium employment level resulting from this bargaining process will not necessarily entail full employment of the union members in the unionized sector. If a union member does not actually get a job in the latter, we assume as usual in this literature that she either finds a job in the competitive sector, or gets an unemployment benefit yielding the same utility level as the latter. These unionized workers ending up employed in the competitive sector are the losers of the union-membership lottery: their ex post utility is lower than that of those who have chosen the competitive sector directly. This is simply a reflection of the fact that the expected utility of joining the union or not are equal in equilibrium. Hence, the benefits accruing ex post to the lucky ones are offset by the losses incurred by the losers, in expected value (see proposition 4 below).

Now, this game must be solved by backward induction, starting by an analysis of the bargaining stage.

\section{The Bargaining Stage}

First, we must define a status quo or fall-back point for each party if no bargain is reached. For the firm, the status quo position is zero: $\bar{V}^{F}=0$. For the union, the status quo position is: $\bar{V}^{u}=\sum_{j \in\{W, B\}} \beta_{j} L_{j}\left(v\left(\bar{w}_{j}\right)+r_{j}-\gamma_{j}\right)$, i.e. the value of the utilitarian objective 
function defined above, when all the union members end up working in the competitive sector or on the dole.

So, the net gain of the firm is given by:

$$
V^{F}-\bar{V}^{F}=\sum_{j \in\{W, B\}}\left(\theta_{j}(N)-w_{j}-\alpha \sigma_{j}^{2}\right) N_{j}
$$

The net gain of the union is:

$$
V^{u}-\bar{V}^{u}=\sum_{j \in\{W, B\}} \beta_{j} N_{j}\left(v\left(w_{j}\right)-v\left(\bar{w}_{j}\right)\right)
$$

The solution concept that we use here is the generalized Nash bargaining solution. Wages and employment are determined by the maximization of the product of each agent's gain from reaching a bargain, weighted by their respective bargaining powers. More precisely, it is derived from :

$$
\operatorname{Max}_{\left\{W_{W}, W_{B}, N_{W}, N_{B}\right\}} \Psi=\left(V^{U}-\bar{V}^{U}\right)^{\lambda}\left(V^{F}-\bar{V}^{F}\right)^{1-\lambda}
$$

where $\lambda$ measures the bargaining power of the union, with $0<\lambda<1$. Then, one can prove the following.

Proposition 2: The outcome of the bargaining between the trade union and the representative firm results in the wage gap between the two groups given by:

$$
w_{W}-w_{B}=\frac{\beta_{W}-\beta_{B}}{\eta \beta_{W}}
$$

where:

$$
\eta=-\frac{v^{\prime \prime}\left(w_{B}\right)}{v^{\prime}\left(w_{B}\right)}
$$

is the percentage slope of the worker's marginal utility, measured positively, or its ArrowPratt degree of absolute risk aversion.

So, the wage gap between the White workers' wage rate and the Black workers' one depends on the two discriminatory parameters introduced in the union utility function, and is independent of the level of the wage rate if the worker's utility function is of the CARA 
type ${ }^{16}$. Hence, statistical discrimination is destroyed in the bargaining process, as the union offers a kind of income-redistribution arrangement to its members, relative to the competitive wage rates. Therefore, this model can be used to explain why unionization seems to reduce discrimination in the case of South Africa, provided we assume that $\beta_{W} / \beta_{B}$ is close enough to one. Then, the roots of any remaining discrimination must be sought in the political economy of trade unionism ${ }^{17}$.

The income-redistribution effect of unionization in this model, consistent with endogenous membership as explained below, requires some additional comments. It is rooted in the ability of the union to raise the average wage, and to redistribute the bonus differentially across the two groups. This is clearly brought out by going one step further in the analysis of the determination of the wage rates. As (12) determines the relative wage of the two types of workers, we just need to look at the average wage, in order to nail down their levels. We need first to establish the following lemma.

Lemma 1: The risk-adjusted rent per worker, defined as the gap between the risk-adjusted expected productivity of each type of labor above its market wage, is equalized across racial groups. Its expression is for $j \in\{W, B\}$ :

$$
\pi=\theta_{j}(N)-\bar{w}_{j}-\alpha \sigma_{j}^{2} \cdot 18
$$

Define $v=N_{W} / N$ as the share of White employment in total employment by the firm. We are now in a position to conclude this analysis of the impact of unionization on wages by establishing the following proposition.

Proposition 3: The average wage bonus due to unionization is determined by the following rent-sharing equation:

\footnotetext{
16 This is at variance with the results in Myles and Naylor (1995), which are not based on statistical discrimination, where the remaining wage gap depends on the union's bargaining power.

${ }^{17}$ See Wintrobe (1998) for a survey on the political economy of trade unions under apartheid.

18 Notice that a meaningful solution to (14) with $\pi \geq 0$ and $N \geq 0$ does not necessarily exist for all values of the exogenous variables and parameters of the model. If it does not for a particular firm, the latter will only hire one type of workers. However, this cannot be true for the representative firm in equilibrium, as the alternative wage would adjust, and we assume here that an interior solution exists.
} 


$$
v w_{W}+(1-v) w_{B}=v \bar{w}_{W}+(1-v) \bar{w}_{B}+\lambda \pi
$$

Notice that this expression (15) is analogous to a standard rent-sharing equation (see e.g. Blanchflower et al., 1996, or Van Reenen, 1996). Hence, the average wage rate in the unionized sector is equal to the average alternative wage plus a rent-sharing term, which is the product of the bargaining power index of the union times the risk-adjusted-rent per worker, measured by valuing labor at its alternative cost.

\section{Determination of Membership}

We now turn our attention to the first stage of this game. As explained above, we assume free entry for workers in the unionized sector, as in Booth (1984). The only constraint that they face at this point is that they must join the union for having a chance to get a job in this sector. They will do so as long as the expected utility from working in a unionized firm is larger than that of working in a competitive one. All the parameters of the model are assumed to be common knowledge, so that the workers are able to form a correct expectation about the wage rates and the employment levels that will come out of the bargaining stage. Then, the determination of membership works as follows.

Define:

$$
\phi_{j}=\left(v\left(w_{j}\right)-v\left(\bar{w}_{j}\right)\right) N_{j}, \quad j \in\{W, B\},
$$

as the aggregate pecuniary benefit from joining the union, which is determined above.

Then, the expected utility that the worker gets from joining the union is:

$$
E_{j}=\frac{\phi_{j}}{L_{j}}+v\left(\bar{w}_{j}\right)+r_{j}-\gamma_{j} .
$$

We can then easily prove the following proposition.

Proposition 4: Under free entry of workers in the unionized sector, (i) equilibrium membership of each group is determined by:

$$
L_{j}^{*}=\frac{\left(w_{j}-\bar{w}_{j}\right) v^{\prime}\left(\bar{w}_{j}\right) N_{j}}{\gamma_{j}-r_{j}} .
$$


(ii) It is stable provided $\gamma_{j}>r_{j}$.

Hence, the level of membership for each group is an increasing function of the wage gap between the unionized and the competitive sectors, of the employment level in the unionized sector, and of the private non-pecuniary benefit enjoyed by the union members. It is obviously decreasing in the cost of union membership. Equation (18) also shows that the wage gap between the union and competitive sectors may be negligible in equilibrium for race $j$ if $\gamma_{j}$ is close to $r_{j}$. As suggested by figure 2, and confirmed in the econometric analysis of section 5 , this is especially relevant for the white workers in our sample.

\section{Empirical Analysis.}

It is straightforward to derive the specification of the empirical model from the theoretical framework presented above. Define the redistribution term $R$ as:

$$
R=\left(\bar{w}_{W}-\bar{w}_{B}\right)-\frac{\beta_{W}-\beta_{L}}{\eta \beta_{W}} .
$$

This is the difference between the competitive wage gap and the bargained wage gap in favor of white workers (see (12)). Hence, $R$ is larger, the more equalizing is the impact of the union on wages. Then, using (7), (12) and (15), one can express the bargained wages as:

$$
\begin{aligned}
& w_{B}=\bar{w}_{B}+\lambda \pi+v R \\
& w_{W}=\bar{w}_{W}+\lambda \pi-(1-v) R
\end{aligned}
$$

Equations (20) and (21) express the benefit of unionization over the competitive wage and reflect the redistribution effect detailed previously: the bargained wage for group $j$ is equal to its alternative wage plus the rent-sharing term plus the redistribution term $R$, which is weighted by the share of the other population group employment in total employment. The proposition that we want to test is the following:

Proposition 5: The racial wage gap is higher in the competitive sector than in the unionized sector:

$$
R>0
$$


This proposition is equivalent to saying that the difference between the White and Black union wage premiums is negative.

\section{Specification.}

In the following, we present some estimates of the sign of this expression using some results of the union wage effect for each racial group computed from a South African data set. We consider here two econometric models. In accordance with the theoretical model, we assume that the union status is endogenously determined. If one believes that union status has merely an intercept effect on wages then the appropriate model to use is a "treatment effects" model. If one thinks that the unionization also has a slope effect, then the switching model is called for. The intuition for the latter is that some of the workers' characteristics (e.g. education) might affect earnings differently in the unionized and in the competitive sectors. We present the results obtained using both specifications below.

The treatment effect model is as follows: Earnings of individual $i$ of race $j\left(W_{i j}\right.$ is here the natural logarithm of the wage) depends on a set of independent variables $X_{i j}$ and on a dummy that accounts for the worker's union status $U_{i j}{ }^{19}$ :

$$
W_{i j}=\beta_{j} X_{i j}+\delta_{j} U_{i j}+\varepsilon_{i j}
$$

$U_{i j}$ is believed to be endogenous and is modeled as the outcome of an unobserved latent variable $U_{i j}^{*}$. It is assumed that $U_{i j}^{*}$ is a linear function of the exogenous covariates $Z_{i j}$ and a random component $u_{i j}$. Specifically,

$$
U_{i j}^{*}=\gamma_{j} Z_{i j}+u_{i j}
$$

and the observed decision is

$$
U_{i j}=\left\{\begin{array}{l}
1 \text { if } U_{i j}^{*}>0 \\
0 \text { otherwise }
\end{array}\right.
$$

\footnotetext{
${ }^{19}$ Another approach for capturing the impact of unionization on wages is to include a measure of union density, as done by Booth and Chatterji (1995). However, this piece of information is not available in our household survey. A matched worker/firm survey would be needed for that.
} 
where, $\left(u_{i j}, \varepsilon_{i j}\right) \sim$ bivariate normal $\left\lfloor 0,0,1, \sigma_{\varepsilon_{j}}, \rho_{j}\right\rfloor$

If unobservable variables influencing the earnings are correlated with the ones affecting union membership, then one is faced with a self-selection problem: $\delta$ doesn't reflect the real value of unionization. Correcting for this self-selection, the wage equation will be as follows:

$$
W_{i j}=\beta_{j} X_{i j}+\delta_{j} U_{i j}+\rho_{j} \sigma_{\varepsilon_{j}}\left(\frac{\phi\left(\gamma_{j} Z_{i j}\right)}{\Phi\left(\gamma_{j} Z_{i j}\right)}\right)+\varepsilon_{i j}
$$

where, $\phi($.$) and \Phi($.$) are respectively the standard normal density and cumulative$ distribution functions. The parameters of this treatment effects model are estimated using a two-step method (Maddala, 1983).

In this case, the union wage effect for each group of workers is computed as :

$$
\hat{\mu}_{j}^{1}=\exp \left(\hat{\delta}_{j}\right)-1
$$

The limitation of this specification is that it imposes that the $\beta_{j}$ are the same for unionized and non unionized workers. However, the theoretical framework discussed above suggests that the impact of unionization may interact with some of the independent variables (e.g. sector of employment). The following specification, based on the switching model, allows for such effects.

Consider two separate earnings regimes for union and non-union members, respectively. Earnings of individual $i$ of race $j$ depend on the worker's union status and are determined according to:

$$
W_{i j}^{u}=\beta_{j}^{u} X_{i j}+\eta_{i j}^{u} \quad \text { if } i \text { is in the union sector }
$$

and

$$
W_{i j}^{n}=\beta_{j}^{n} X_{i j}+\eta_{i j}^{n} \quad \text { if } i \text { is in the non union sector }
$$

As mentioned above, these wage equations are conditional on the union status choice and their estimation by ordinary least squares would produce inconsistent estimates of $\beta$ since workers are not randomly assigned to the union and nonunion sectors. Applying the Heckman's two step estimation procedure, we finally estimate the following wage equations: 


$$
\begin{aligned}
& W_{i}^{u}=\beta_{1 j}^{u} X_{i j}^{u}+\beta_{2 j}^{u}\left(-\frac{\phi\left(\gamma_{j} Z_{i j}\right)}{\left(1-\Phi\left(\gamma_{j} Z_{i j}\right)\right)}\right)+\eta_{i j}^{u} \\
& W_{i}^{n}=\beta_{1 j}^{n} X_{i j}^{n}+\beta_{2 j}^{n}\left(-\frac{\phi\left(\gamma_{j} Z_{i j}\right)}{\left(1-\Phi\left(\gamma_{j} Z_{i j}\right)\right)}\right)+\eta_{i j}^{n}
\end{aligned}
$$

The union earnings premium is: $\hat{\mu}_{j}^{2}=\exp \left(\left(\beta_{j}^{n}-\beta_{j}^{n}\right) \bar{X}\right\rfloor-1$, where the vector $\bar{X}$ contains the means of the variables computed using the union and non union sample ${ }^{20}$.

Depending on the assumptions made on the model $(m=1$ for the treatment effect model and 2 for the switching model), for testing proposition 5, we are interested in the sign of the following differences: $\hat{\mu}_{W}^{m}-\hat{\mu}_{B}^{m}$.

\section{The Data Set and Variables ${ }^{21}$.}

The data are derived from the 1999 October Household Survey conducted by Statistics South Africa22. A two-stage sampling procedure was applied in the OHS, and the sample was stratified, clustered and selected to meet the requirements of probability sampling. The survey covers 30000 households of all races. Only employed persons from age 15 to 65 are considered here. Females, self-employed as well as workers with nonpositive or unspecified wages or hours of work are omitted from the sample. Observations with missing data on any variable included in the earnings and unionization functions were disregarded. The domestic sector, which does not provide any jobs for White employees and remains almost unaffected by unionization is also excluded from the sample. Then, the sample consists of 6610 Black and 1114 White male wage-earning employees.

The earnings variable is the logarithm of hourly earnings, where earnings are defined as the total wage or salary (including overtime and bonus) before tax. When the workers only report the income interval in which her income fits, we use the mid-point of this

\footnotetext{
${ }^{20}$ There is no agreement in the literature concerning the choice of the vector of means characteristics. It can be the vector computed either on the union sample or the non union sample or the whole sample. Furthermore, the differential will be interpreted here as an unconditional differential; i.e. the selection terms are set to zero.

${ }^{21}$ The description and means of variables are presented in the appendix, in table 1A.

22 The first reliable South African survey including data on union status is dated from 1993. Since then, Statistics South Africa has produced annual surveys (the October Household Survey from 1995 to 1999 and the General Household Survey from 2002 to 2004) as well as half-yearly survey (the Labor Force Survey from 2000 to 2004).
} 
interval $(40 \% \text { of the sample })^{23}$. Moreover, to abstract from the effect of variations in hours worked, the earnings data were converted into hourly data using the information given by the workers on the number of hours they usually work per week. The explanatory variables in the earnings equation include the standard human capital measures (schooling, experience, tenure - as a proxy for on-the-job-learning), a dummy for union membership, one for the marital status (as a proxy for factors such as stability, motivation and discipline), some job characteristics (occupational level24, industrial sectors, formal sector) as well as location variables (a urban dummy and province dummies, in order to take into account the differences in the cost of living, as well as sectoral effects).

The union status variable available is whether or not the worker is a paid-up member ${ }^{25}$. Its determinants are all the independent variables introduced in the earnings equation plus some exclusive variables which are assumed to have an influence on the union membership but not on the earnings ${ }^{26}$. A dummy Other union members indicates whether there are other persons in the household who are also union member. According to Moll (1993), this variable reflects household-specific tastes for unionization, such as political orientation and the willingness to invest union dues for the sake of long security and wage gains. We also include the ratio of young in the household to the number of wage earners (dependence ratio). It is assumed that workers with larger needs at home are more likely than others to join a union, as a means of enhancing job security. A dummy denoting the presence

\footnotetext{
${ }^{23}$ We alternatively ran interval regressions which allow to process estimates on income interval data. In our case, the results are almost identical to the OLS estimates using the mid-points. However, in order to take into account the selection effect, we choose the Heckman's model instead of the generalized tobit model.

${ }_{24}$ An attempt was made to consider the occupational categories as endogenous, introducing the predicted probabilities of being in a particular occupation instead of the actual occupation. Unfortunately, due to the low number of observations for white workers, the multinomial logit results are too weak to be trustable.

${ }^{25}$ An additional piece of information would be desirable for capturing the impact of unionization, namely the establishment union status. However, this is not available in the household survey used here, and would require a matched worker/firm survey. Nevertheless, we know that the probability that a firm is unionized or not depends a lot on its sector of activity, and we control for several characteristics of the latter in the estimated equations.

${ }^{26}$ Unfortunately, the survey does not contain obvious variables that could be used for identification, such as union dues for instance.
} 
of unemployed persons in the household (unemployed in the household) is also included for the same purpose.

\section{Results ${ }^{27}$.}

Table 4 presents the estimates of the union wage premium for both White and Black workers derived from the two econometric models specified earlier. In order to test proposition 5, the difference in the union effect between the two population groups is computed as well. Whichever model is considered, only Black union members earn significantly more than non-union members do. There is no evidence of a union wage premium for White workers. This result is common in the literature on the union wage premium in South Africa ${ }^{28}$. Within the present framework, it must be interpreted in the light of (20) and (21). The positive union premium for Black workers does not tell us much about proposition 5 , as a very strong rent-sharing term $\lambda \pi$ might more than offset a perverse redistribution effect $R$. However, the non significant union premium for White workers suggests that the inequality-reducing union effect, highlighted in proposition 5 above, is approximately of the same magnitude as the rent-sharing effect, so that they almost exactly cancel out. Moreover, the White-Black difference in this union wage effect is negative and statistically significant, according to the final row of table 4 . This empirical result also implies that one cannot discard proposition 5 , namely that $R>0$, and thus, that the racial wage gap is higher in the competitive sector than in the unionized sector.

\footnotetext{
${ }^{27}$ The results of the estimates of the earnings equations for the two models are displayed in the appendix, tables $2 \mathrm{~A}, 3 \mathrm{~A}$ and $4 \mathrm{~A}$. The determinants of union membership are estimated in table $5 \mathrm{~A}$.

${ }_{28}$ As a comparison, using the simple OLS model and considering the union status as exogenously determined, we find a union premium of $26.9 \%$ for Black workers and $0.5 \%$ (but insignificant) for Whites. These figures are more in accordance with Butcher and Rouse (2001) and Mwabu and Schultz (2000) results using the same methodology. The substantial difference with the outcome derived here for Blacks comes from the correction for sample selection. Indeed, we find that the self-selection correction term in the treatment effect model is negative and significant for Blacks (see table 2A). This means that unobserved characteristics make Black people with a higher probability of unionization more likely to receive lower wages. Not taking into account this sample selection effect thus underestimates the real wage effect of unionization. In the case of White workers, the correction for the selectivity bias doesn't appear to be necessary.
} 
Table 4: Estimates of the Inequality-Reducing Effect of Unionization

\begin{tabular}{lcc}
\hline & \multicolumn{2}{c}{ Union wage effect (in \%) } \\
\cline { 2 - 3 } White workers (1) & Treatment effects model & Switching model \\
\cline { 2 - 3 } & 2.98 & 6.90 \\
Black workers (2) & $(0.1669)$ & $(0.1738)$ \\
& $100.46^{*}$ & $83.82^{*}$ \\
$(1)-(2)$ & $(0.2712)$ & $(0.2766)$ \\
& $-97.47^{*}$ & $-76.92^{*}$ \\
& $(0.3058)$ & $(0.3274)$ \\
\hline
\end{tabular}

Source: OHS 1999.

Notes : standard errors in parentheses are computed using the bootstrap method.

$\left(^{*}\right)$ : statistically significant at the $5 \%$ level.

Moreover, tables 3.A and 4.A, in the appendix, provide a little more information on the incidence of the union effect across industries and regions. The last two columns show that the inequality-reducing effect of unionization is not equally significant in all the rows. Hence, as predicted by the theoretical model, there are sectors of employment where unionized and non unionized workers are paid the same. Unfortunately, the household survey used here does not allow to go any further in distinguishing the different types of firms, while this would be desirable for a finer testing of the theoretical framework. A matched data set, including data for workers and for the firms that employ them would be required for that. Nevertheless, these tables show that some of this relevant heterogeneity is captured here, by the various dummy variables indicating the different sectors and regions. As expected, this is more noticeable for Black workers.

\section{Conclusion.}

The main result of this model is that, in a situation of efficient bargaining in which the firm would impose statistical discrimination against a group of workers under competitive conditions, the intervention of a trade union may remove this kind of discrimination. The union raises the average wage, at the cost of a lower employment level in the unionized firm, and may redistribute the bonus in favor of the discriminated workers. However, wage discrimination may persist, but this time due to the discrimination imbedded in the union's preferences, through the parameters of its utility function. Hence, the roots of the 
discrimination occurring in the unionized sector should be sought in the political economy of trade unionism. After the fall of apartheid in South Africa, it seems plausible that this form of discrimination has been dampened considerably. Thus, by removing the effect of statistical discrimination, this finding suggests that the union gives rise to a form of private income redistribution in favor of the workers belonging to the racial group which would otherwise suffer from statistical discrimination.

This theoretical result seems to be confirmed by the econometric analysis presented in section 5. The latter shows that the impact of unionization on wages seems to be higher for Black workers than for White workers, who get on average roughly the same wage when they are unionized as when they are not. We thus find that the racial wage gap is reduced under union bargaining.

The theory and empirical evidence presented in this paper thus point to the legal framework for industrial relations, insofar as it affects the political economy of trade unionism, and to the policy towards human capital development, as the two crucial elements of a policy aiming at making the South African labor market more equitable.

\section{References}

Allanson, P., Atkinks, J. P. and T. Hinks (2000), “A multilateral decomposition of racial wage differentials in the 1994 South African Labour Market", Journal of Development Studies, 37 (1), 93-120.

Aigner, D. and C. Cain (1977), "Statistical theories of discrimination in labor markets", Industrial and Labor Relations Review, 30 (2), 175-87.

Arrow, K. (1972), "The theory of discrimination", Discrimination in Labor Markets, O. Ashenfelter et A. Rees (ed), Princeton University Press, Princeton, New jersey.

Becker, G. (1957), The Economics of Discrimination, University of Chicago Press.

Blanchflower, D. G., A. J. Oswald and P. Sanfey (1996), “Wages, profits, and rent-sharing”, Quarterly Journal of Economics, 111(1), 227-251.

Booth, A. (1984), "A public choice model of trade union behaviour and membership", Economic Journal, 94 (376), 883-98. 
Booth, A. (1985), "The free rider problem and a social custom theory of trade union membership", Quarterly Journal of Economics, 100, fev, 253-261.

Booth, A. and M. Chatterji (1993), “Reputation membership and wages in an open shop trade union", Oxford Economic Papers, 45 (1), 23-41.

Booth, A. and M. Chatterji (1995), “Union membership and wage bargaining when membership is not compulsory", Economic Journal, 105 (429), 345-360.

Booth, A. (1995), The Economics of Trade Union, Cambridge University Press.

Butcher K. and C. Rouse (2001), "Wage effects of unions and industrial councils in South Africa", Industrial and Labor Relations Review, 54 (2), 349-74.

Case, A. and A. Deaton (1996), "School inputs and educational outcomes in South Africa", Quarterly Journal of Economics, 114 (3), 1947-84.

Crankshaw, O. (1997), Race, class and the changing division of labour under apartheid, Routledge, London.

Fallon, P. and R. Lucas (1997), “South African labor markets adjustment and inequalities", mimeo, World Bank, May.

Frijters, P. (1999), “Hiring on the basis of expected productivity in a South African clothing firm", Oxford Economic Paper, 51 (2), 345-54.

Griffiths H. and R. Jones (1980), "Discrimination in the labor market", South African Labor Economics, McGraw-Hill book company, Johannesburg.

Hinks T. and D. Watson (2001), "A multinomial logit nondiscriminatory approach to estimating racial wage and occupational discrimination", Applied Economics, 33, 60512.

Hofmeyr J. and R. Lucas (2001), “The rise in union wage premiums in South Africa”, Labour, $15(4), 685-719$.

Knight, J. and M. McGrath (1977), “An analysis of racial wage discrimination in South Africa", Oxford Bulletin of Economics and Statistics, 39 (November), 245-71.

Knight, J. and M. McGrath (1987), “The erosion of apartheid in the South African labor market : measures and mechanism", Applied Economics Discussion Paper $n^{\circ} 35$, Institute of Economics and Statistics, Oxford. 
Lundberg, S. and R. Startz, (1983), "Private discrimination and social intervention in competitive labor markets", American Economic Review, 73 (June), 340-47

Maddala. G. (1983), Limited-dependent and qualitative variables in econometrics. Cambridge University Press.

McDonald, I. and R. Solow (1981), "Wage bargaining and employment", American Economic Review, 71 (5), 896-908

Moll, P. (1992), “The decline of discrimination against colored people in South Africa 19751985", Journal of Development Economics, 37, 289-307.

Moll, P. (1993), “Black South African unions: relative wage effects in international perspective", Industrial and Labor Relations Review, 46 (2), 245-61.

Moll, P. (1995), “Wage Developments in South Africa in the 1990s”, mimeo.

Moll, P. (1998), "Primary schooling, cognitive skills and wages in South Africa", Economica, 65 (258), 263-84.

Mwabu, G. and P. Schultz (1998), “Labor unions and the distribution of wages and employment in South Africa", Industrial Labor Relation Review, 51 (4), 680-703.

Mwabu, G. and P. Schultz (2000), "Wage premiums for education and location of South African workers, by gender and race", Economic Development and Cultural Change, $48(2), 307-34$

Myles, G. and R. Naylor. (1995), “Do unions reduce discrimination? A model of Nash bargaining between a union and an employer with discriminatory tastes", Labor Economics, 2 (3), 249-74.

Naylor, R. (1989), "Strikes, free riders and social customs", Quarterly Journal of Economics, 104 (4), 771-786.

Naylor, R. and M. Cripps (1993), "An economic theory of the open shop trade union", European Economic Review, 37, 1599-1601.

Nickell, S. (1982), A Bargaining model of the Phillips curve, Centre for Labor Economics, London School of Economics, Discussion Paper n ${ }^{\circ} 30$.

Oettinger, G. (1996), "Statistical discrimination and the early career evolution of the BlackWhite wage gap", Journal of Labor Economics, 14 (1), 52-78. 
Phelps, E. (1972), “The statistical theory of racism and sexism”, American Economic Review, 62 (4), 659-61.

Rospabé, S. (2001), “Making racial wage relations fair in South Africa: a focus on the role of trade unions ", DPRU Working Paper, n01/48, Cape Town.

Rospabé, S. (2002), "How did labour market racial discrimination evolve after the end of apartheid?", South African Journal of Economics, 70(1), 185-217.

Standing, G., Sender, J. and J. Weeks (1996), Restructuring the labor market: the South African challenge. An ILO Country Review. Geneva : International Labor Office.

Thomas, D. (1996), "Education across generations in South Africa”, American Economic Review Papers and Proceedings, 86 (2), 330-34.

Van Reenen, J. (1996), “The creation and capture of rents: wages and innovation in a panel of U.K. companies", Quarterly Journal of Economics, 111 (1), 195-226.

Wintrobe, R. (1998), The political economy of dictatorship, Cambridge University Press. 


\section{Appendices}

Proof of Proposition 1: Expected profit can be written as:

$$
E(\Pi)=\sum_{j \in\{W, B\}}\left[\theta_{j}(N)-\bar{w}_{j}\right] N_{j}
$$

Thus, (5) amounts to:

$$
\operatorname{Max}_{\left\{N_{W}, N_{B}\right\}} V^{F}=\sum_{j \in\{W, B\}}\left[\theta_{j}(N)-\bar{w}_{j}-\alpha \sigma_{j}^{2}\right] N_{j}
$$

The first-order conditions for this maximization problem are for $j \in\{W, B\}$ :

$$
\frac{\partial V^{F}}{\partial N_{j}}=E_{j}^{\prime}(N)-\bar{w}_{j}-\alpha \sigma_{j}^{2}=0
$$

Then, rearranging the terms yields :

$$
\bar{w}_{j}=E_{j}^{\prime}(N)-\alpha \sigma_{j}^{2} .
$$

In words, the wage rate for each group is equal to the expected marginal productivity of a worker from that group (see (4)), corrected by the risk factor characteristic of that group ${ }^{29}$. Thus, subtracting (A.4) for Blacks from (A.4) for whites allows to write the wage differential as in (7). QED.

Proof of Proposition 2: Let us consider the first order conditions with respect to $w_{W}$ and $w_{B}$, $j \in\{W, B\}:$

$$
\frac{\lambda}{1-\lambda} \beta_{j} v^{\prime}\left(w_{j}\right)\left(V^{F}-\bar{V}^{F}\right)=V^{u}-\bar{V}^{U}
$$

The ratio of (A.7) for the two groups yields:

$$
\frac{\beta_{W}}{\beta_{B}} \frac{v^{\prime}\left(w_{W}\right)}{v^{\prime}\left(w_{B}\right)}=1
$$

This expression can be solved for the wage gap. Defining $\eta$ as in (13), one can use a Taylor expansion of $v^{\prime}\left(w_{W}\right)$ about $w_{B}$ to write (12). QED

\footnotetext{
${ }^{29}$ It can be shown easily that the wage rate for each group is a decreasing function of the level of employment of workers from the other group. Hence, this model could provide micro-foundations for an analysis of apartheid, somewhat related to the discussion in Wintrobe (1998). Here, white workers would benefit from restricting access by Black workers to the firms in which they work, by the socalled pass system, which was in force under apartheid, at the expense of their employers. Hence, the number of Black workers in the representative firm would then depend on the relative bargaining power of white workers and their employers.
} 
Proof of Lemma 1: We need first to derive the second set of first-order conditions, with respect to $N_{W}$ and $N_{B}$ :

$$
\frac{\lambda}{1-\lambda} \beta_{j}\left[v\left(w_{j}\right)-v\left(\bar{w}_{j}\right)\right]\left(V^{F}-\bar{V}^{F}\right)+\left(V^{U}-\bar{V}^{u}\right)\left[E_{j}^{\prime}(N)-w_{j}-\alpha \sigma_{j}^{2}\right]=0
$$

From this first-order conditions, using the ratios of (A.9) to (A.7) for the two groups, and using a Taylor expansion of $v\left(\bar{w}_{j}\right)$ about $w_{j}$, one can derive two equations that determine implicitly $N$ and $v$ :

and

$$
\theta_{W}(N)+N\left(v \theta_{W}{ }^{\prime}(N)+(1-v) \theta_{B}^{\prime}(N)\right)=\bar{w}_{W}+\alpha \sigma_{W}^{2},
$$

$\theta_{B}(N)+N\left(v \theta_{W}{ }^{\prime}(N)+(1-v) \theta_{B}{ }^{\prime}(N)\right)=\bar{w}_{B}+\alpha \sigma_{B}^{2}$.

These two equations, similar in some respects to (A.3) and (A.4), show that the level of employment of each type of worker is chosen such that the expected marginal productivity of each type of worker is equal to her alternative wage cost, corrected by the risk factor characteristic of her group. Then (14) is easily derived from (A.10). QED

Proof of Proposition 3: We need to derive an expression for the average wage from (A.9). Using (A.7) and (A.8), and defining $v=N_{W} / N$ as the share of White employment in total employment by the firm, these expressions can be arranged to read:

$$
\begin{aligned}
& v w_{W}+(1-v) w_{B}= \\
& \quad v\left(\theta_{W}(N)-\alpha \sigma_{W}^{2}+(1-\lambda) N \theta_{W}{ }^{\prime}(N)\right)+(1-v)\left(\theta_{B}(N)-\alpha \sigma_{B}^{2}+(1-\lambda) N \theta_{B}{ }^{\prime}(N)\right)
\end{aligned}
$$

Therefore, the average wage rate is increasing with the average productivity of the two types of workers, decreasing in the average variance of their productivity, and increasing in the bargaining power of the trade union. A close examination of (A.11) shows that the latter effect results from the ability of the union to offset the negative impact on the marginal productivity of each type of worker that the firm can have by increasing employment. In other words, the union acquires the means to redistribute wages across groups by restricting the total employment level in the firm. Equation (A.11) does not determine fully the average wage, as it is not a reduced form, $N$ and $v$ remaining to be 
determined. Nevertheless, the effect sketched above holds true also in equilibrium, as shown in proposition 3.

Using (A.10) together with (14), one can derive (15) easily, taking into account the fact that:

$$
\pi=-\left(N_{W} \theta_{W}{ }^{\prime}(N)+N_{B} \theta_{B}{ }^{\prime}(N)\right) \cdot \text { QED }
$$

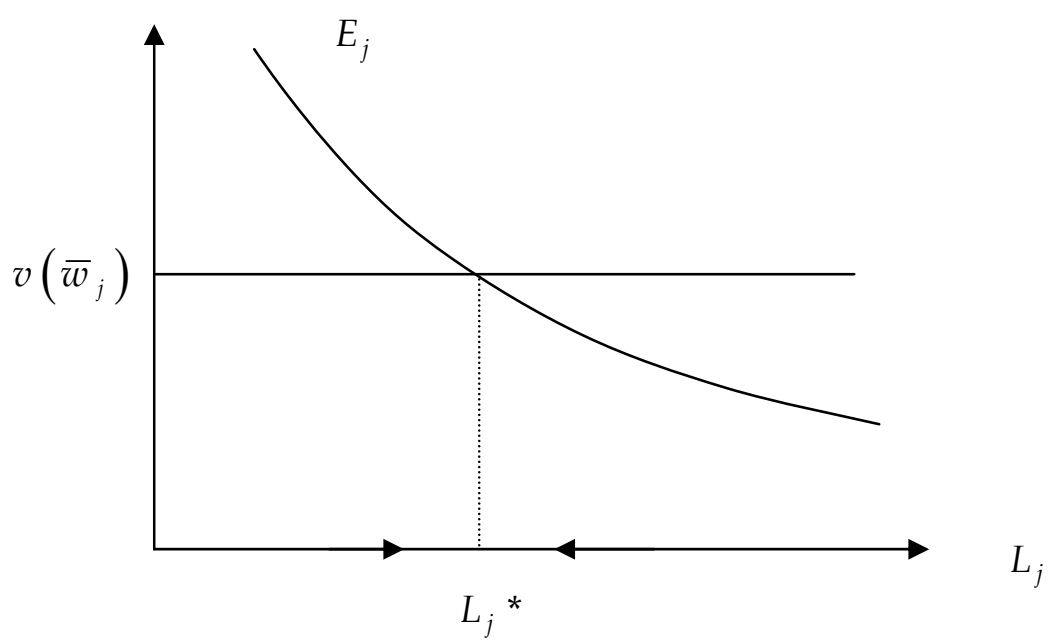

Figure A.1: Entry into the Unionized Sector

Proof of Proposition 4: Notice first that $\phi_{j}>0$ if $w_{j}>\bar{w}_{j}$. As union membership can obviously not be negative, (18) shows that $w_{j}>\bar{w}_{j}$ if $\gamma_{j}>r_{j}$, in equilibrium. Assuming the latter to hold, the dynamics of entry into the unionized sector can be analyzed with the help of figure A.1. The downward sloping hyperbola represents (17). The horizontal line drawn at the $v\left(\bar{w}_{j}\right)$ level represents the utility level reached by the type $j$ worker if she chooses the competitive sector. Entry occurs as long as the hyperbola lies above the horizontal line, while exit occurs in the opposite case. The arrows drawn on the horizontal axis show that the resulting dynamics converges to $L_{j}^{*}=\frac{\phi_{j}}{\gamma_{j}-r_{j}}$, where $E_{j}=v\left(\bar{w}_{j}\right)$.

Then, (18) is derived by using a Taylor expansion of $v\left(w_{j}\right)$ about $\bar{w}_{j}$, and substituting for $\phi_{j}$. QED 
Table 1A. Definition of the Variables and Descriptive Statistics.

\begin{tabular}{|c|c|c|c|}
\hline \multirow[t]{2}{*}{ Variable } & \multirow[t]{2}{*}{ Description } & \multicolumn{2}{|c|}{$\begin{array}{c}\text { Mean and standard } \\
\text { deviation }\end{array}$} \\
\hline & & $\begin{array}{l}\text { White } \\
\text { workers }\end{array}$ & $\begin{array}{c}\text { Black } \\
\text { workers }\end{array}$ \\
\hline & $\begin{array}{l}\text { Dependent: } \\
\end{array}$ & & \\
\hline Union member & $=1$ if is a union paid-up member & $0.40(0.49)$ & $0.47(0.50)$ \\
\hline \multirow[t]{2}{*}{ Earnings } & Logarithm of the hourly earnings & $3.23(0.95)$ & $1.77(1.12)$ \\
\hline & $\begin{array}{l}\text { Independent: } \\
\text { Union membership and earnings equation }\end{array}$ & & \\
\hline Years of schooling & $=$ number of years of schooling & $12.25(1.70)$ & $7.49(4.19)$ \\
\hline $\begin{array}{l}\text { Years of } \\
\text { schooling*tertiary }\end{array}$ & $\begin{array}{l}=\text { number of years of schooling*dummy for } \\
\text { tertiary education (technical and university } \\
\text { diploma, above matric) }\end{array}$ & $5.47(6.74)$ & $1.14(3.75)$ \\
\hline Age & $=$ age & $36.86(11.21)$ & $37.20(10.20)$ \\
\hline Age square & $=$ age square & $1484.4(876.3)$ & $1487.9(809.7)$ \\
\hline Tenure & $=$ years of seniority within the present firm & $8.35(8.88)$ & $7.81(8.27)$ \\
\hline Tenure square & $=$ tenure square & $148.6(326.1)$ & $129.4(275.6)$ \\
\hline Married & $=1$ if married, civilly or traditionally & $0.69(0.46)$ & $0.54(0.50)$ \\
\hline \multirow[t]{3}{*}{$\begin{array}{l}\text { Occupational } \\
\text { categories }\end{array}$} & $\begin{array}{l}\text { highly skilled: managers, professionals, semi- } \\
\text { professionals and technicians }\end{array}$ & $0.52(0.50)$ & $0.11(0.32)$ \\
\hline & $\begin{array}{l}\text { skilled: Clerks, salesperson and skilled service } \\
\text { workers, skilled agricultural workers and }\end{array}$ & $0.37(0.48)$ & $0.41(0.49)$ \\
\hline & $\begin{array}{l}\text { artisans) } \\
\text { unskilled (ref): Operators, routine workers }\end{array}$ & $0.11(0.31)$ & $0.48(0.50)$ \\
\hline Formal sector & $\begin{array}{l}=1 \text { if works in the formal sector (fiscal registration } \\
\text { of the employer) }\end{array}$ & $0.98(0.15)$ & $0.89(0.32)$ \\
\hline \multirow[t]{9}{*}{ Sectors } & Agriculture & $0.05(0.22)$ & $0.18(0.39)$ \\
\hline & Mining & $0.09(0.29)$ & $0.15(0.36)$ \\
\hline & Manufacturing (ref) & $0.18(0.39)$ & $0.15(0.35)$ \\
\hline & Utility & $0.01(0.12)$ & $0.01(0.12)$ \\
\hline & Construction & $0.03(0.16)$ & $0.08(0.28)$ \\
\hline & Trade & $0.17(0.38)$ & $0.13(0.33)$ \\
\hline & Transport & $0.10(0.30)$ & $0.06(0.24)$ \\
\hline & Finance & $0.17(0.38)$ & $0.06(0.23)$ \\
\hline & Service & $0.20(0.40)$ & $0.17(0.38)$ \\
\hline Urban & $=1$ if lives in a urban area & $0.90(0.30)$ & $0.57(0.49)$ \\
\hline \multirow[t]{10}{*}{ Province } & Gauteng (ref) & $0.35(0.48)$ & $0.20(0.40)$ \\
\hline & Western Cape & $0.18(0.38)$ & $0.06(0.23)$ \\
\hline & Eastern Cape & $0.10(0.29)$ & $0.07(0.26)$ \\
\hline & Northern Cape & $0.06(0.25)$ & $0.03(0.18)$ \\
\hline & Free State & $0.10(0.30)$ & $0.13(0.33)$ \\
\hline & Kwazulu Natal & $0.05(0.22)$ & $0.13(0.34)$ \\
\hline & North West & $0.04(0.21)$ & $0.14(0.35)$ \\
\hline & Mpumalanga & $0.08(0.27)$ & $0.13(0.34)$ \\
\hline & Northern province & $0.04(0.21)$ & $0.10(0.30)$ \\
\hline & Union membership equation only & & \\
\hline Other union member & $\begin{array}{l}=1 \text { if other individuals in the household are paid- } \\
\text { up union member. }\end{array}$ & $0.22(0.41)$ & $0.13(0.33)$ \\
\hline Dependence ratio & $\begin{array}{l}=\text { number of children under } 15 / \text { number of wage } \\
\text { earners }\end{array}$ & $0.55(0.79)$ & $0.83(1.22)$ \\
\hline $\begin{array}{l}\text { Unemployed in the } \\
\text { household }\end{array}$ & $\begin{array}{l}=1 \text { if some individuals in the household are } \\
\text { unemployed }\end{array}$ & $0.08(0.27)$ & $0.31(0.46)$ \\
\hline
\end{tabular}


Table 2A. Determinants of Earnings (Treatment Effects Model)

\begin{tabular}{|c|c|c|c|c|c|c|}
\hline \multirow{2}{*}{$\begin{array}{l}\text { Dependent variable: } \\
\text { ln hourly wage }\end{array}$} & \multicolumn{2}{|c|}{ White workers (1) } & \multicolumn{2}{|c|}{ Black workers (2) } & \multicolumn{2}{|c|}{ (1) - (2) } \\
\hline & Coefficient & St. error & Coefficient & St. error & Coefficient & St. error \\
\hline Years of schooling & $0.0632^{\star *}$ & 0.0206 & $0.0376^{*}$ & 0.0035 & 0.0256 & 0.0209 \\
\hline Years of schooling*tertiary & $0.0100 * *$ & 0.0050 & $0.0330^{*}$ & 0.0038 & $-0.0230^{\star}$ & 0.0062 \\
\hline Age & $0.0716^{*}$ & 0.0158 & $0.0371^{*}$ & 0.0075 & $0.0344^{\star \star}$ & 0.0175 \\
\hline Age square & $-0.0008^{*}$ & 0.0002 & $-0.0004^{*}$ & 0.0001 & $-0.0004^{\star \star *}$ & 0.0002 \\
\hline Tenure & $0.0142^{* *}$ & 0.0064 & $0.0109 * *$ & 0.0038 & 0.0033 & 0.0075 \\
\hline Tenure square & -0.0001 & 0.0001 & $-0.0002^{\star *}$ & 0.0001 & 0.0001 & 0.0002 \\
\hline Married & $0.1203^{\star \star *}$ & 0.0616 & $0.1040^{*}$ & 0.0257 & 0.0162 & 0.0668 \\
\hline Union member & 0.0294 & 0.1481 & $0.6954^{*}$ & 0.1161 & $-0.6660^{*}$ & 0.1882 \\
\hline High skilled occupationa & $0.7696^{*}$ & 0.0880 & $0.4316^{*}$ & 0.0450 & $0.3380^{*}$ & 0.0989 \\
\hline Skilled occupation & $0.3569^{*}$ & 0.0844 & $0.0724^{\star *}$ & 0.0249 & $0.2845^{\star \star}$ & 0.0880 \\
\hline Formal sector & $0.3804^{\star \star}$ & 0.1519 & $0.1305^{\star \star}$ & 0.0442 & 0.2499 & 0.1582 \\
\hline Agriculture $^{b}$ & $-0.5437^{*}$ & 0.1432 & $-0.7168^{\star}$ & 0.0529 & 0.1731 & 0.1527 \\
\hline Mining & $0.2134^{\star \star}$ & 0.1033 & $-0.1769^{\star}$ & 0.0542 & $0.3903^{*}$ & 0.1167 \\
\hline Utility & -0.1483 & 0.2077 & $0.1847^{* *}$ & 0.0934 & -0.3330 & 0.2278 \\
\hline Construction & -0.1189 & 0.1551 & 0.0374 & 0.0524 & -0.1563 & 0.1637 \\
\hline Trade & $-0.3389^{*}$ & 0.0829 & $-0.1777^{\star}$ & 0.0432 & $-0.1612^{\star \star \star}$ & 0.0935 \\
\hline Transport & -0.0889 & 0.0947 & -0.0241 & 0.0507 & -0.0648 & 0.1074 \\
\hline Finance & -0.0411 & 0.0788 & -0.0783 & 0.0542 & 0.0372 & 0.0957 \\
\hline Service & $-0.2180^{\star \star}$ & 0.0821 & 0.0465 & 0.0441 & $-0.2645^{\star \star}$ & 0.0932 \\
\hline Urban & 0.1456 & 0.0999 & $0.1249^{*}$ & 0.0273 & 0.0207 & 0.1036 \\
\hline Western Cape & $0.1611^{\star \star}$ & 0.0682 & $0.0954^{\star \star \star}$ & 0.0519 & 0.0657 & 0.0857 \\
\hline Eastern Cape & $-0.1893^{\star *}$ & 0.0942 & $-0.4075^{\star}$ & 0.0485 & $0.2182^{* *}$ & 0.1059 \\
\hline Northern Cape & -0.1432 & 0.1098 & -0.0692 & 0.0651 & -0.0740 & 0.1276 \\
\hline Free State & $-0.1717^{\star \star}$ & 0.0864 & $-0.4652^{*}$ & 0.0405 & $0.2935^{\star \star}$ & 0.0954 \\
\hline Kwazulu Natal & -0.0675 & 0.1089 & -0.0493 & 0.0396 & -0.0182 & 0.1159 \\
\hline North West & -0.0765 & 0.1197 & $-0.1795^{\star}$ & 0.0400 & 0.1030 & 0.1262 \\
\hline Mpumalanga & -0.0070 & 0.0956 & $-0.1341^{*}$ & 0.0402 & 0.1271 & 0.1037 \\
\hline Northern province & -0.0978 & 0.1170 & $-0.1135^{\star \star}$ & 0.0454 & 0.0158 & 0.1254 \\
\hline Intercept & -0.1202 & 0.4010 & 0.2458 & 0.1521 & -0.3660 & 0.4289 \\
\hline Lambda & -0.0161 & 0.0921 & $-0.2788^{\star}$ & 0.0689 & $0.2628^{\star \star}$ & 0.1151 \\
\hline Wald test (intercept only) & $\begin{array}{l}\text { Chi2 } \\
839.11\end{array}$ & $\begin{array}{c}\text { Prob }>\text { Chi2 } \\
0.00\end{array}$ & $\begin{array}{c}\text { Chi2 } \\
6848.89\end{array}$ & $\begin{array}{c}\text { Prob }>\text { Chi2 } \\
0.00\end{array}$ & & \\
\hline $\begin{array}{l}\text { Chow test (constant coeff. } \\
\text { between (1) and (2)) }\end{array}$ & $\begin{array}{c}F \\
21.22\end{array}$ & $\begin{array}{c}\text { Prob }>\text { F } \\
0.00\end{array}$ & & & & \\
\hline $\mathrm{N}$ & 1114 & & 6613 & & & \\
\hline
\end{tabular}

Source: OHS 1999.

Notes : * statistically significant at the $1 \%$ level, ${ }^{* *}$ the $5 \%$ level and ${ }^{* * *}$ the $10 \%$ level. Reference categories: (a) low-skilled occupation, (b) manufacturing, (c) Gauteng 
Table 3A. Determinants of Earnings (Switching Model) - White workers

\begin{tabular}{|c|c|c|c|c|c|c|}
\hline \multirow{2}{*}{$\begin{array}{l}\text { Dependent variable: } \\
\text { ln hourly wage }\end{array}$} & \multicolumn{2}{|c|}{ Union members (1) } & \multicolumn{2}{|c|}{ Non union members (2) } & \multicolumn{2}{|c|}{$(1)-(2)$} \\
\hline & Coefficient & St. error & Coefficient & St. error & Coefficient & St. error \\
\hline Years of schooling & $0.0713^{* *}$ & 0.0321 & $0.0618^{* *}$ & 0.0272 & 0.0095 & 0.0421 \\
\hline Years of schooling*tertiary & 0.0017 & 0.0078 & $0.0140^{* *}$ & 0.0065 & -0.0123 & 0.0101 \\
\hline Age & $0.0730^{* *}$ & 0.0286 & $0.0698^{*}$ & 0.0200 & 0.0032 & 0.0349 \\
\hline Age square & $-0.0008^{* *}$ & 0.0004 & $-0.0008^{*}$ & 0.0003 & 0.0000 & 0.0004 \\
\hline Tenure & 0.0153 & 0.0094 & 0.0132 & 0.0115 & 0.0020 & 0.0149 \\
\hline Tenure square & -0.0001 & 0.0002 & -0.0001 & 0.0004 & 0.0000 & 0.0004 \\
\hline Married & 0.0964 & 0.0938 & $0.1557^{* * *}$ & 0.0821 & -0.0593 & 0.1247 \\
\hline High skilled occupationa & $0.5376^{*}$ & 0.1337 & $0.8886^{*}$ & 0.1189 & $-0.3510^{* *}$ & 0.1789 \\
\hline Skilled occupation & $0.2097^{* * *}$ & 0.1224 & $0.4618^{*}$ & 0.1164 & -0.2521 & 0.1689 \\
\hline Formal sector & 0.1755 & 0.3236 & $0.3860^{* *}$ & 0.1725 & -0.2106 & 0.3667 \\
\hline Agriculture $^{\mathrm{b}}$ & 0.0515 & 0.3653 & $-0.6753^{*}$ & 0.1623 & $0.7268^{* * *}$ & 0.3998 \\
\hline Mining & $0.3775^{* *}$ & 0.1476 & 0.1175 & 0.1530 & 0.2600 & 0.2126 \\
\hline Utility & -0.1848 & 0.2765 & 0.0418 & 0.3212 & -0.2266 & 0.4238 \\
\hline Construction & $0.7593^{* *}$ & 0.2844 & $-0.4346^{* *}$ & 0.1846 & $1.1939^{*}$ & 0.3390 \\
\hline Trade & -0.0451 & 0.1549 & $-0.4326^{*}$ & 0.0995 & $0.3876^{* *}$ & 0.1841 \\
\hline Transport & 0.0000 & 0.1339 & -0.0544 & 0.1383 & 0.0543 & 0.1925 \\
\hline Finance & 0.2232 & 0.1489 & -0.1234 & 0.0927 & $0.3465^{\star *}$ & 0.1754 \\
\hline Service & -0.0268 & 0.1194 & $-0.2297^{* *}$ & 0.1167 & 0.2028 & 0.1669 \\
\hline Urban & $0.3569 * *$ & 0.1669 & 0.0708 & 0.1258 & 0.2860 & 0.2090 \\
\hline Western Cape ${ }^{c}$ & 0.1297 & 0.1222 & $0.1857^{* *}$ & 0.0824 & -0.0560 & 0.1474 \\
\hline Eastern Cape & -0.1263 & 0.1233 & $-0.2621^{* * *}$ & 0.1465 & 0.1358 & 0.1915 \\
\hline Northern Cape & -0.0326 & 0.1651 & -0.2013 & 0.1468 & 0.1687 & 0.2209 \\
\hline Free State & -0.1945 & 0.1258 & -0.1121 & 0.1187 & -0.0824 & 0.1729 \\
\hline Kwazulu Natal & -0.1488 & 0.1805 & -0.0220 & 0.1347 & -0.1268 & 0.2252 \\
\hline North West & 0.1402 & 0.1862 & $-0.2896^{* * *}$ & 0.1558 & $0.4298^{\star * *}$ & 0.2428 \\
\hline Mpumalanga & 0.0480 & 0.1405 & -0.0002 & 0.1340 & 0.0482 & 0.1942 \\
\hline Northern province & -0.0401 & 0.1895 & -0.0942 & 0.1478 & 0.0541 & 0.2403 \\
\hline Intercept & -0.1829 & 0.7563 & -0.0074 & 0.4886 & -0.1754 & 0.9004 \\
\hline Lambda & -0.1362 & 0.1200 & -0.0958 & 0.1466 & -0.0404 & 0.1895 \\
\hline Wald test (intercept only) & $\begin{array}{c}\text { Chi2 } \\
380.78\end{array}$ & $\begin{array}{c}\text { Prob> Chi2 } \\
0.00\end{array}$ & $\begin{array}{c}\text { Chi2 } \\
726.42\end{array}$ & $\begin{array}{c}\text { Prob }>\text { Chi2 } \\
0.00\end{array}$ & & \\
\hline & $\mathrm{F}$ & Prob $>$ F & & & & \\
\hline $\begin{array}{l}\text { Chow test (constant coeff. } \\
\text { between (1) and (2)) }\end{array}$ & 1.22 & 0.4665 & & & & \\
\hline $\mathrm{N}$ & 444 & & 670 & & & \\
\hline
\end{tabular}

Source: OHS 1999.

Notes : * statistically significant at the $1 \%$ level, ${ }^{* *}$ the $5 \%$ level and ${ }^{* * *}$ the $10 \%$ level. Reference categories: (a) low-skilled occupation, (b) manufacturing, (c) Gauteng 
Table 4A. Determinants of Earnings (Switching Model) - Black workers

\begin{tabular}{|c|c|c|c|c|c|c|}
\hline \multirow{2}{*}{$\begin{array}{l}\text { Dependent variable: } \\
\text { ln hourly wage }\end{array}$} & \multicolumn{2}{|c|}{ Union members (1) } & \multicolumn{2}{|c|}{ Non union members (2) } & \multicolumn{2}{|c|}{$(1)-(2)$} \\
\hline & Coefficient & St. error & Coefficient & St. error & Coefficient & St. error \\
\hline Years of schooling & $0.0417^{*}$ & 0.0049 & $0.0327^{*}$ & 0.0050 & 0.0090 & 0.0070 \\
\hline Years of schooling*tertiary & $0.0295^{*}$ & 0.0044 & $0.0426^{*}$ & 0.0064 & $-0.0131^{* * *}$ & 0.0077 \\
\hline Age & $0.0318^{* *}$ & 0.0121 & $0.0368^{*}$ & 0.0100 & -0.0050 & 0.0157 \\
\hline Age square & $-0.0003^{* *}$ & 0.0001 & $-0.0004^{* *}$ & 0.0001 & 0.0000 & 0.0002 \\
\hline Tenure & $0.0218^{*}$ & 0.0063 & 0.0051 & 0.0054 & $0.0168^{* *}$ & 0.0083 \\
\hline Tenure square & $-0.0004^{* *}$ & 0.0002 & -0.0001 & 0.0001 & -0.0003 & 0.0002 \\
\hline Married & $0.1013^{* *}$ & 0.0340 & $0.1030^{* *}$ & 0.0373 & -0.0018 & 0.0505 \\
\hline High skilled occupationa & $0.3368^{*}$ & 0.0549 & $0.5502^{*}$ & 0.0703 & $-0.2134^{* *}$ & 0.0892 \\
\hline Skilled occupation & $0.0914^{* *}$ & 0.0325 & 0.0320 & 0.0368 & 0.0594 & 0.0491 \\
\hline Formal sector & $0.4073^{*}$ & 0.1239 & 0.0384 & 0.0549 & $0.3689^{* *}$ & 0.1355 \\
\hline Agriculture $^{b}$ & $-0.8225^{*}$ & 0.0922 & $-0.5935^{*}$ & 0.0727 & $-0.2291^{* \star *}$ & 0.1174 \\
\hline Mining & $-0.1591^{* *}$ & 0.0634 & $-0.2337^{* *}$ & 0.1130 & 0.0746 & 0.1296 \\
\hline Utility & 0.1019 & 0.1093 & 0.2429 & 0.1527 & -0.1411 & 0.1878 \\
\hline Construction & $-0.2478^{* *}$ & 0.0923 & $0.1555^{\star *}$ & 0.0683 & $-0.4033^{*}$ & 0.1148 \\
\hline Trade & $-0.1721^{* *}$ & 0.0625 & $-0.1675^{\star *}$ & 0.0591 & -0.0046 & 0.0860 \\
\hline Transport & $0.1193^{* * *}$ & 0.0663 & $-0.1508^{* *}$ & 0.0734 & $0.2701^{* *}$ & 0.0989 \\
\hline Finance & $-0.2369^{* *}$ & 0.0773 & -0.0008 & 0.0740 & $-0.2361^{* *}$ & 0.1070 \\
\hline Service & 0.0698 & 0.0530 & 0.0562 & 0.0720 & 0.0136 & 0.0894 \\
\hline Urban & $0.0914^{* *}$ & 0.0342 & $0.1652^{*}$ & 0.0417 & -0.0737 & 0.0540 \\
\hline Western Cape ${ }^{c}$ & 0.0904 & 0.0750 & 0.0619 & 0.0718 & 0.0285 & 0.1038 \\
\hline Eastern Cape & $-0.2500^{*}$ & 0.0632 & $-0.5505^{*}$ & 0.0712 & $0.3005^{* *}$ & 0.0952 \\
\hline Northern Cape & $0.1762^{* *}$ & 0.0811 & $-0.3030^{* *}$ & 0.1008 & $0.4792^{*}$ & 0.1294 \\
\hline Free State & $-0.2089^{*}$ & 0.0518 & $-0.7065^{*}$ & 0.0605 & $0.4977^{*}$ & 0.0796 \\
\hline Kwazulu Natal & -0.0136 & 0.0554 & $-0.1112^{* *}$ & 0.0556 & 0.0976 & 0.0785 \\
\hline North West & -0.0303 & 0.0501 & $-0.3063^{*}$ & 0.0612 & $0.2759^{*}$ & 0.0791 \\
\hline Mpumalanga & 0.0485 & 0.0524 & $-0.3018^{*}$ & 0.0592 & $0.3503^{*}$ & 0.0791 \\
\hline Northern province & $0.1029^{* * *}$ & 0.0573 & $-0.3194^{*}$ & 0.0687 & $0.4223^{*}$ & 0.0895 \\
\hline Intercept & 0.4669 & 0.3549 & 0.3256 & 0.2012 & 0.1413 & 0.4080 \\
\hline Lambda & -0.0253 & 0.0987 & $0.4631^{*}$ & 0.1076 & $-0.4884^{*}$ & 0.1460 \\
\hline Wald test (intercept only) & $\begin{array}{c}\text { Chi2 } \\
3001.60\end{array}$ & $\begin{array}{c}\text { Prob }>\text { Chi2 } \\
0.00\end{array}$ & $\begin{array}{c}\text { Chi2 } \\
3232.19\end{array}$ & $\begin{array}{c}\text { Prob }>\text { Chi2 } \\
0.00\end{array}$ & & \\
\hline $\begin{array}{l}\text { Chow test (constant coeff. } \\
\text { between (1) and (2)) }\end{array}$ & $\begin{array}{c}F \\
8.29\end{array}$ & $\begin{array}{c}\text { Prob }>\text { F } \\
0.00\end{array}$ & & & & \\
\hline $\mathrm{N}$ & 3119 & & 3494 & & & \\
\hline
\end{tabular}

Source: OHS 1999.

Notes : * statistically significant at the $1 \%$ level, ${ }^{* *}$ the $5 \%$ level and ${ }^{* * *}$ the $10 \%$ level. Reference categories: (a) low-skilled occupation, (b) manufacturing, (c) Gauteng 
Table 5A. The Determinants of Union Membership.

\begin{tabular}{|c|c|c|c|c|}
\hline \multirow{2}{*}{$\begin{array}{l}\text { Dependent variable : } \\
\text { Union membership }\end{array}$} & \multicolumn{2}{|c|}{ White workers } & \multicolumn{2}{|c|}{ Black workers } \\
\hline & Coefficient & St. error & Coefficient & St. error \\
\hline Years of schooling & $-0.0803^{* *}$ & 0.0398 & $0.0255^{*}$ & 0.0060 \\
\hline $\begin{array}{l}\text { Years of schooling *tertiary } \\
\text { schooling }\end{array}$ & 0.0030 & 0.0097 & -0.0004 & 0.0062 \\
\hline Age & $0.1050^{*}$ & 0.0315 & $0.0589 *$ & 0.0133 \\
\hline Age square & $-0.0015^{*}$ & 0.0004 & $-0.0007^{*}$ & 0.0002 \\
\hline Tenure & $0.0578^{*}$ & 0.0108 & $0.0838^{*}$ & 0.0058 \\
\hline Tenure square & $-0.0005^{* *}$ & 0.0003 & $-0.0017^{*}$ & 0.0002 \\
\hline Married & -0.1215 & 0.1274 & $0.1260^{* *}$ & 0.0432 \\
\hline High skilled occupation ${ }^{a}$ & $-0.5376^{*}$ & 0.1656 & -0.0409 & 0.0746 \\
\hline Skilled occupation & -0.0532 & 0.1600 & $0.0792 * * *$ & 0.0424 \\
\hline Formal sector & -0.0453 & 0.2884 & $1.0178^{*}$ & 0.0808 \\
\hline Agriculture $^{b}$ & $-0.6158^{* *}$ & 0.3029 & $-0.8712^{*}$ & 0.0736 \\
\hline Mining & $0.5466^{* *}$ & 0.1834 & $1.0447^{*}$ & 0.0719 \\
\hline Utility & 0.4860 & 0.3703 & 0.0443 & 0.1468 \\
\hline Construction & -0.2303 & 0.3020 & $-0.5053^{*}$ & 0.0836 \\
\hline Trade & $-0.3180^{* *}$ & 0.1612 & $-0.3024^{*}$ & 0.0659 \\
\hline Transport & $0.3610^{* *}$ & 0.1758 & -0.0296 & 0.0811 \\
\hline Finance & -0.1497 & 0.1554 & $-0.2343^{* *}$ & 0.0838 \\
\hline Service & $0.6444^{*}$ & 0.1447 & $0.3622^{*}$ & 0.0663 \\
\hline Urban & 0.1397 & 0.1930 & 0.0320 & 0.0475 \\
\hline Western Cape & 0.0917 & 0.1348 & $0.3201^{*}$ & 0.0832 \\
\hline Eastern Cape & $0.7815^{*}$ & 0.1675 & $0.2379 * *$ & 0.0815 \\
\hline Northern Cape & $0.3790 * * *$ & 0.2101 & $0.3910^{*}$ & 0.1151 \\
\hline Free State & $0.3965^{* *}$ & 0.1582 & $0.1434^{* *}$ & 0.0685 \\
\hline Kwazulu Natal & 0.2138 & 0.2119 & 0.0814 & 0.0666 \\
\hline North West & 0.1088 & 0.2265 & $0.2076^{* *}$ & 0.0673 \\
\hline Mpumalanga & $0.3984^{* *}$ & 0.1735 & $0.2511^{*}$ & 0.0659 \\
\hline Northern province & 0.1827 & 0.2211 & $0.2865^{*}$ & 0.0760 \\
\hline Dependence ratio & 0.0374 & 0.0624 & 0.0074 & 0.0162 \\
\hline Other union members & $1.1828^{*}$ & 0.1108 & $0.6719^{*}$ & 0.0557 \\
\hline Unemployed in the household & 0.1249 & 0.1586 & -0.0057 & 0.0411 \\
\hline Intercept & $-1.7685^{* *}$ & 0.7934 & $-3.1453^{*}$ & 0.2754 \\
\hline $\mathrm{N}$ & 1114 & & 6613 & \\
\hline$\%$ of obs. correctly predicted & $76.93 \%$ & & $77.74 \%$ & \\
\hline
\end{tabular}

Source : OHS 1999.

Notes : * statistically significant at the $1 \%$ level, ** the $5 \%$ level and *** the $10 \%$ level. Reference categories: (a) low-skilled occupation, (b) manufacturing, (c) Gauteng 